\title{
Innovations and External Growth Strategy: The Case of Oil and Gas Supply and Service Companies
}

\author{
S. Barreau' \\ 1 Institut français du pétrole, École du pétrole et des moteurs, Centre économie et gestion, \\ 228-232, avenue Napoléon-Bonaparte, 92852 Rueil-Malmaison Cedex - France \\ e-mail: sebastien.barreau@ifp.fr
}

\begin{abstract}
Résumé - Innovations et stratégie de croissance externe : le cas des entreprises parapétrolières L'industrie des services pétroliers située en amont de la chaîne des hydrocarbures (l'industrie parapétrolière) a connu une importante vague de consolidation depuis le début des années 1990. En effet, nombreuses ont été les entreprises de ce secteur à avoir eu recours à une politique de croissance externe afin de se renforcer sur leurs activités de base, d'élargir la gamme des services fournis, ou encore, de modifier intégralement leurs activités. Aujourd'hui, le secteur parapétrolier est caractérisé par l'existence d'un oligopole formé de trois Majors parapétrolières (Baker Hughes, Halliburton et Schlumberger) et d'une frange concurrentielle composée de nombreux acteurs de taille plus modeste.

Dans cet article, en nous basant sur les travaux de l'économiste J.A. Schumpeter, nous nous proposons de fournir une explication originale à l'évolution stratégique des trois compagnies leaders des services parapétroliers. En effet, J.A. Schumpeter a analysé le processus de diffusion des innovations au sein d'un secteur industriel, que nous appliquons au cas des trois entreprises leaders du secteur parapétrolier. Alors que le terme innovation s'entend généralement comme le résultat du progrès technique, nous l'utilisons dans cet article conformément à la définition de Schumpeter, pour lequel une innovation peut aussi bien être la fabrication d'un nouveau bien qui s'adresse à une nouvelle demande, l'introduction d'une nouvelle méthode de production ou de commercialisation, l'ouverture d'un nouveau marché, l'utilisation d'une nouvelle matière première ou d'un nouveau bien intermédiaire, que la réalisation d'une nouvelle organisation.

Nous justifions ensuite la réorganisation du secteur parapétrolier amont dans son ensemble par le fait que le processus de diffusion des innovations mis en évidence au sein de l'oligopole reste tout à fait pertinent pour justifier la vague de réorganisation de la frange concurrentielle du secteur parapétrolier. Cette démarche nous amène enfin à envisager les modalités de la consolidation que le secteur va continuer à connaitre lors des prochaines années.
\end{abstract}

\footnotetext{
Abstract - Innovations and External Growth Strategy: The Case of Oil and Gas Supply and Service Companies - The upstream oil and gas service sector has been going through a wave of consolidations since 1990. Indeed, many firms in this sector have adopted an external growth strategy in order to strengthen their core business, broaden their range of provided products or reorganize their activities. Nowadays, the upstream oil and gas service sector is characterized by the presence of an oligopoly which is composed of three Major service and supply firms (Baker Hughes, Halliburton and Schlumberger) and numerous smaller oil and gas service businesses.
} 
In this article, based on the research work of the economist J.A. Schumpeter, we first provide an original explanation for the strategic development of the three leading oil and gas service and supply firms. J.A. Schumpeter has in fact analyzed the process of disseminating innovation within an industrial sector that applies in the case of the three leading oil and gas service firms. Whereas the term innovation generally means the result of technical progress, we use it in this article in the context of Schumpeter for whom an innovation can be the manufacture of a new product as a result of a new demand, the launching of a new method of production or marketing, the opening of a new market, the use of a new raw or intermediate material, or the establishment of a new organization.

Secondly, we justify the reorganization of the overall upstream service and supply sector by the fact that the process of disseminating innovation, to which we gave prominence within the oligopoly, remains relevant to justify the same reorganization of the many smaller oil and gas service firms. This process leads us to consider the form of consolidation that the sector will experience over the next few years.

\section{INTRODUCTION}

This article is concerned with the wave of consolidations that the upstream oil and gas service and supply industry has been going through since 1990. Scores of companies in this sector have relied on an external growth policy designed to reinforce their core business, to broaden their range of services, and to fully revamp their operations. The oil and gas service and supply sector today is distinguished by the existence of an oligopoly formed of three Majors (Baker Hughes, Halliburton and Schlumberger) and numerous smaller oil and gas service businesses that we will call the competitive fringe.

The aim of this article is to provide an original justification for this wave of consolidations. The first part describes the work of Schumpeter (1942) on the evolution of an industrial sector, in which the author finds that every company that implements an innovation is imitated by one or more competitors.

The second part of the article is devoted to analyzing the oil and gas service and supply sector. We begin this analysis by examining the strategies of the companies making up the oligopoly and identify a development pattern for these three firms, of the "one leader-two followers" type.

The third part attempts to test the hypothesis according to which the three companies of the oligopoly act as leaders for the companies in the competitive fringe. If this hypothesis were to be substantiated, we could accordingly justify the reorganization of these companies and this approach would ultimately lead us to consider the consolidation arrangements that this sector will continue to see in the coming years.

\section{THE WORK OF SCHUMPETER ON THE EVOLUTION OF AN INDUSTRIAL SECTOR}

\subsection{Schumpeter's Economic Circuit}

Schumpeter's view of the "business world" is chiefly based on the question of economic equilibrium. Unlike a state of static equilibrium, Schumpeter (1935) prefers a dynamic concept of "economic circuit" that he defines as a reference state, hypothetical and abstract, designed to perform an essentially instrumental function. This state, close to Walrasian ${ }^{1}$ equilibrium, lacks any change of internal origin (i.e. without entrepreneur) and is characterized by production organized according to the "routines" in place.

Le Dortz (1999) states that "the Schumpeterian development is defined as a shift in this state of equilibrium, discontinuous in its pattern and economic in its origin."

Let us state that the circuit, close to equilibrium, is always temporary because "one can never attain a state that fully corresponds to the complete absence of development" (Schumpeter, 1935, p. 349). However, the search for equilibrium emerges as a prerequisite to the initiation of economic development. In fact, only a situation close to equilibrium can provide the necessary security and calm for the development of innovations.

\subsection{Schumpeter's Concept of Innovation}

Companies implement strategies via different levers: by influencing the number of companies, by differentiating between products and/or factors of production, by erecting barriers and by controlling the flow of information.

Schumpeter (1947) lumps these strategies under a single name: innovation. Innovation consists in industrializing the object of a discovery and then successfully introducing it on the market. According to the author, capitalism, which he defines as "a type or a method of economic transformation" (Schumpeter, 1947, p. 115) is characterized by a developmental process. This evolutionary character is driven by five types of innovation ${ }^{2}$ - or new combinations (Table 1).

(1) For Schumpeter, in fact, this circuit is only close to equilibrium because "one can never attain a state that fully corresponds to the lack of development" (Schumpeter, 1935, p. 349).

(2) Schumpeter does not overlook the role played by transformations of the social and natural environment (like wars and revolutions) of economic life in the evolution of capitalism. Nor does he overlook the growth of population and capital, or the role played by monetary systems. However, the basic impetus is the implementation of the innovations as he defines them. 
TABLE 1

Schumpeter's five types of innovation

\begin{tabular}{l|l}
\hline 1 & $\begin{array}{l}\text { The production of a new product (of better quality or designed } \\
\text { to respond to new demand) }\end{array}$ \\
2 & The introduction of a new production or marketing method \\
3 & The opening of a new market \\
4 & The use of a new raw or intermediate material \\
5 & The establishment of a new organization \\
\hline
\end{tabular}

Source: Schumpeter (1947, p. 116)

This list of innovations includes technological, commercial and organizational innovations alike. If, like Bienaymé (1994), we define technological innovation as the commercial and lucrative application of a principle concerning the relations between the producer and nature, innovations of types 1, 2 and 4 specifically address this case. Note also that novelty is not total, insofar as a combination already exploited on a market may be novel when applied on a new market or geographic space.

These industrial revolutions occur discontinuously (in waves) or in clusters. In fact, as stated by Le Dortz (1999), if innovation were continuous, the economic system would never be at equilibrium (or close to equilibrium) and would therefore not experience cyclic regularities. Similarly, if innovation remained an isolated act, individual innovations would be progressively assimilated without any disturbing effects on the economic circuit: "The disturbances caused by the continuous emergence of new entrepreneurs can be continuously resorbed; on the contrary the emergence of a group of entrepreneurs dictates a specific process of resorption, a process of adaptation to the new product, and a process of liquidation of the economy" (Schumpeter, 1935, p. 232).

\subsection{The Development of an Industrial Sector}

By retranscribing this concept of innovation to the sectorbased level, we can infer that an established industry experiences periods of relative calm during its development, close to a situation of equilibrium, punctuated by industrial revolutions provoked by waves of radical innovations. The achievement of these new combinations "periodically redesigns the existing structure of the industry, by introducing new production methods [...], new products [...], new forms of organization - such as company mergers; new sources of supply [...], new trading routes and new markets for buying and for selling" (Schumpeter, 1947, p. 97).

Thus economic development assumes the form of a cycle consisting of a boom phase and a depression phase. In qualitative terms, it is accompanied by a process of creative destruction (or industrial revolution) which "revolutionizes the economic structure from inside by continually destroying new elements. These revolutions are not incessant: they occur in disjointed thrusts, separated from each other by periods of relative calm" (Schumpeter, 1947, p. 116).

In Schumpeter's view, innovations have a strong strategic content. They enable the companies who launch them to benefit from monopoly factors, putting into question the model of perfect competition: "The introduction of new production methods and new goods is difficult to conceive if, from the outset, the innovators were faced with conditions of perfect and perfectly rapid competition. [...] In fact, perfect competition is and always has been temporarily suspended [...] whenever a novelty has been introduced, even if the conditions were [...] perfectly competitive" (Schumpeter, 1947, p. 144-145). The process of creative destruction then goes beyond traditional competition through prices. This competition, spurred by innovation, relies on a decisive superiority in terms of costs and quality, and erodes the foundations of the firms and their very existence. Finally, if the monopoly power conferred on the innovation remains transitory, neither the process innovation nor the product innovation suffice to guarantee a stable dominant position.

\subsection{The Schumpeterian Cycle: A Synthesis}

The Schumpeterian cycle hence begins with the establishment of an innovation by an entrepreneur and the search for monopoly power (new product, new process, new market, new source of raw material or new form of organization). This innovation enables the firm to increase its profits. Then competing (or potentially competing) companies can try to imitate the innovation. Hence it is at this stage that the followers appear. The innovation thus becomes ordinary, with the result of lower profits for the competing companies. The sector thus approaches equilibrium until the triggering of a new economic cycle driven by an innovation.

This illustrates a strategic pattern of the "leaderfollower(s)" type. A leader firm implements an innovation and the play of competition means that one or more competing companies - the followers-imitate it. Then the same company, or a competing firm, assumes the leadership role to innovate and within a variable period of time, it is imitated by competitors.

To examine the oil and gas supply and service sector, we first identify this "leader-follower" pattern within an oligopoly formed of three companies (Baker Hughes, Halliburton and Schlumberger) which clearly dominate the oil and gas service market. The oil and gas supply and service industry has in fact witnessed the emergence of four Major innovations (in the Schumpeterian sense) since the late 1980s, for which we can, for each of them, identify the innovative role played by one of these three firms and the follower strategy adopted by the other two. This is the subject of the second part. 


\section{INNOVATIONS IN THE OIL AND GAS SUPPLY AND SERVICE INDUSTRY}

Before presenting the innovations occurring in the oil and gas supply and service industry in the past decade, we shall begin this part with a brief description of the sector concerned.

\subsection{Brief Description of the Upstream Oil and Gas Supply and Service Sector}

The oil and gas exploration-production industry is composed of two main groups of players, consisting of the oil companies on the one hand, and the oil and gas supply and service companies on the other, the latter being the subcontractors of the former for a number of activities and services. The services rendered by the oil and gas supply and service industry are broken down into three distinct industrial segments (Fig. 1). The first is geophysics, for which these service and supply firms operate in five activities: the acquisition of seismic data, the processing of these data, their interpretation, management and storage of these data, and the manufacture of seismic equipment.

Once the drilling location has been identified by a seismic survey, the oil and gas supply and service companies act again to drill and also to perform services associated with exploratory drilling (wireline logging, mud logging) and with production drilling (completion, horizontal and defected drilling). Added to this is the construction of the drill bits. Supply and service operations also include construction and offshore engineering (construction and positioning of drilling platforms) and miscellaneous subsea operations.

The oil and gas supply and service industry can be considered as an oligopoly consisting of three leading firms

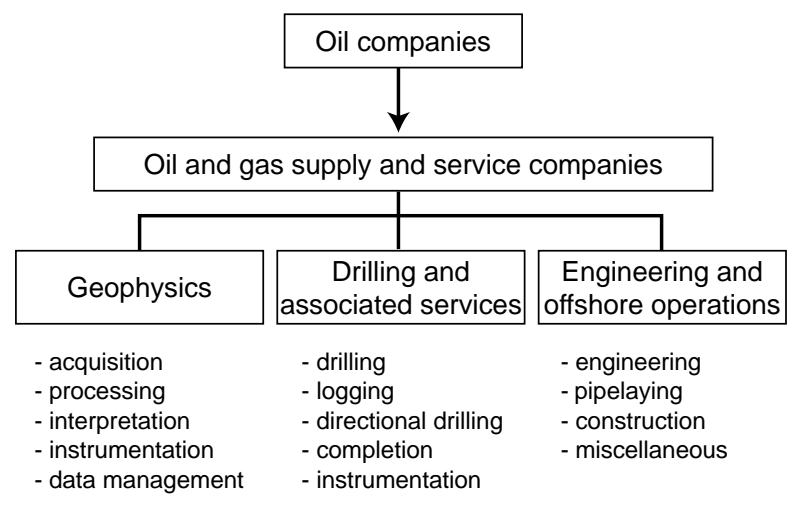

Figure 1

Presentation of the oil and gas supply and service sector. and a competitive fringe of smaller players. The three leader groups dominate the sector because of the range of services provided (closely integrated firms) as well as the market shares they hold in numerous supply and service activities: they are genuine integrated groups often qualified as oil and gas supply and service Majors (Annex 1).

The competitive fringe is composed of numerous smaller firms in geophysical prospecting, drilling and engineering and offshore operations. This article only considers geophysics and drilling companies on the list given in Annex 2.

\subsection{Innovations ${ }^{3}$ and "Leader-Follower" Pattern in the Oligopoly}

We can identify four Major innovations that have occurred in the oil and gas supply and service sector. These innovations were initially launched by one of the three leading firms and were quickly imitated by the other two. The first of these innovations (2.2.1) is organizational. It occurred in the late 1980s and consisted of the firms' redefinition of their activity portfolios. The second innovation, for the same firms, consisted in broadening the range of their services by external growth (2.2.2). This strategy spread over a period from 1992 to 1996. The third innovation (2.2.3) occurred in 1998 and, for these firms, consisted in Major mergersacquisitions which culminated in huge stock transfers from 1999 on. Developments in e-business and the advent of the new economy appears to be the fourth innovation (2.2.4) witnessed by the oil and gas supply and service sector.

\subsubsection{Redefinition of the Activity Portfolio}

In the late 1980s, a few years after the 1986 oil aftershock, a strategic mutation occurred, and continued for several years in the oil and gas supply and service industry. This is in fact the period that saw the wave of redefinition of the frontiers of the firms in this industry. This strategic development is clearly an innovation in the Schumpeterian sense of the term, insofar as Schumpeter considered the establishment of a new organization as a type of new combinations-or innovations (Table 1).

This development resulted from a sector crisis that accompanied a slump in crude oil prices (Fig. 2) which led the oil companies to drastically cut their explorationproduction budgets, the main source of income of the supply and service companies.

Faced with a declining market, the supply and service companies were forced to draw up restructuring plans driven by the more efficient utilization of their production capability.

The company that emerged as the leader in this innovation is Halliburton, which refocused on some of its activities

(3) We use the term innovation to comply with Schumpeter's terminology. Yet in the text, we replace this term by reorganization, mutation or even evolution. 


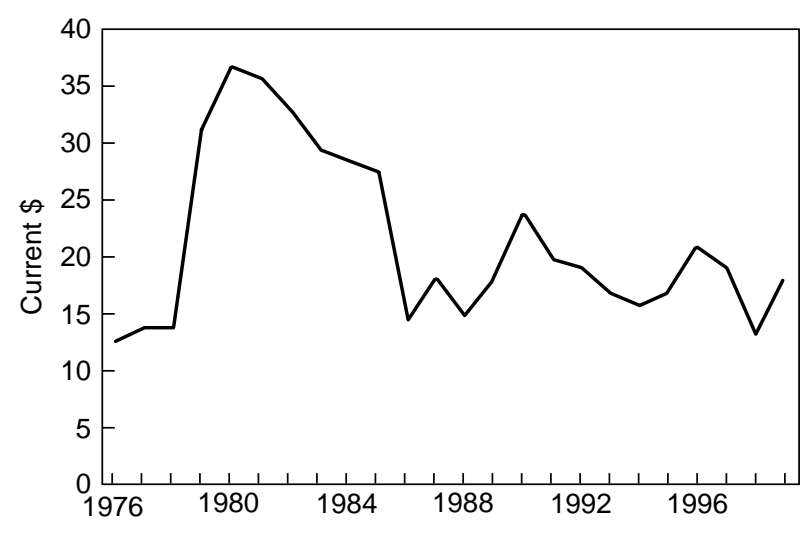

Figure 2

Brent price in current dollars.

from 1986 to 1989 , and consolidated by absorbing other trades. Reinforced activities included drilling fluids with the creation of a joint venture in 1986, M-I Drilling Fluids, with a division of Dresser, seismics (acquisitions of Gearhart Industries and 60\% of GSI in 1988 and Sierra Geophysics in 1989).

This strategy, imposed by an unfavorable competitive environment, was speedily imitated by Baker Hughes in 1987 and until 1994. Baker Hughes wanted to preserve operations offering attractive margins, as well as those in which the group was number one or two worldwide. Thus Baker Hughes reinforced its submersible pumps activity (acquisition of Edeco in 1989), instrumentation (acquisitions of Vetco Gray in 1987, Bird Machine in 1989, Tracor and Elder Oil Tools in 1990) and chemicals (acquisitions of Chemlink and Ceda Reactor in 1990). Measurements while drilling (MWD) and directional drilling were also reinforced with the acquisitions of Eastman Christensen in 1990 and Teleco in 1992.

The group also refocused by selling off its pipe inspection operations as well as non-service and supply measurement and control operations (sale of the $E M \& C$ group in 1993 and 1994).

The same development pattern was witnessed at Schlumberger between 1988 and 1993, which reinforced its information systems ${ }^{4}$, seismic and 3D software ${ }^{5}$, wireline logging and measurements during drilling activities, as well as cementing. The group also sold its defense and graphic operations in 1988.

(4) Creation of a research laboratory in Austin because of the growing use of software and computers in oil and gas service operations. Similarly, Schlumberger acquired Geoquest Systems in 1992.

(5) Acquisitions of $25 \%$ of Geco in 1988, of Sonics in 1989, of Deft Geophysical in 1990, of 51\% of Prakla-Seismos in 1991 and Seismograph Service in 1992. This wave of seismic acquisitions followed a first wave which began before the oil aftershock.
Thus for this innovation, which consisted in setting up a new organization (by altering the operational frontiers of the firms), we have a "leader-follower" pattern, or more precisely a "one leader-two followers" pattern, which recurred in the three developments described below.

\subsubsection{Broadening of the Range of Services}

The second innovation, which can be qualified as Schumpeterian, occurred between 1992 and 1996 and, for the three firms examined, consisted in broadening the range of services supplied in order to propose an integrated service. This innovation was driven by the demand of the oil companies, which decided to subcontract more operations to the supply and service companies.

The provision of geophysics and drilling services does not require the installation of specific assets from the standpoint of the oil companies (Teece, 1978). The theory of transaction costs, developed by Williamson $(1975,1985)$, states that in case of low specificity of the assets, the company is better off-externalizing the operations. Thus the oil companies externalized a growing number of activities, thereby offering the supply and service companies a new market and encouraging the implementation of new working methods, materialized by the search for alliances and partnerships.

This was a typical Schumpeterian innovation insofar as this reorganization, which occurred among the oil company clients, offers a new market to the oil and gas supply and service companies, the market for integrated services. The demand for a new product was identified by Schumpeter as being a type of innovation (Table 1).

The company that played the leader role among these three firms is Baker Hughes, whose chairman J.D. Woods said in 1993: "The nature of the relationship between our customer, the oil and gas companies, and the service industry has fundamentally changed and will continue to change over the remainder of the decade. By being involved in a larger scope of services from the early stages of well planning, service companies can gain efficiencies for the operator and earn incentives for themselves, thus creating win-win economies for both." This strategic customer-focused approach materialized in the creation of the Baker Hughes Inteq Division, which led to the supply of integrated services and the search for partnerships with oil and gas clients. Baker Hughes became the first service industry company to acquire such an entity.

The competition promptly responded. In 1994, Halliburton created the Halliburton Energy Services Division, which combined all the energy operations of the group. Its chairman, T.H. Cruikshank, stated: "Halliburton Energy Services offers a broad range of products and services using a single management structure and consistent business practices across all geographic areas. Joint efforts involving Halliburton Energy Services and Brown \& Root's engineering and project management capabilities offer unique opportunities to 
optimize the development of large oil and gas fields. Consequently, we are well positioned to provide total solutions to customer needs, not just discrete, stand-alone services." He added: "We are the broadest array of oil fields products and services in the world. Yet, because of how they are now integrated into Halliburton Energy Services, we have a very lean structure. Further, we are very flexible and can react quickly to market trends. Because of our infrastructure, we are in an excellent position to interface with clients. Basically, each customer has one contact point for all our services. We are now in an excellent position to provide total solutions rather than just discrete services." This customeroriented strategy was accompanied by an internal restructuring that caused the group to sell off its geophysics operations and create Halliburton Drilling Systems, including the directional drilling operations acquired from Smith (in 1992, to offer customers a range of directional well-drilling services, MWD, Measurement While Drilling), LWD, Logging While Drilling)).

The implementation of this strategy was initially less pronounced at Schlumberger, although in 1994, the group organized itself into eleven world-scale product lines, with closer attention paid to customers, the aim of the strategy being to shorten the product development cycle. New working methods were installed, first with the launch of the DESC program (Design and Evaluation Services for Customers) in fluid engineering and pumping services, the launch of the ClientLink program aimed to exploit the synergies between the different companies in the group (Sedco-Forex, Dowell and Anadrill), and the search for alliances with oil and gas customers. Yet it was only in 1997 that the group assumed a clear position as a supplier of comprehensive solutions. Schlumberger subdivided each activity group into two organizations: "Solutions" which became the real interface with customers, and "Products", based on expertise in existing product lines, which took charge of the development of technology, services and assistance.

The supply of this new type of service, integrated service, thus developed according to a "one leader-two followers" pattern.

\subsubsection{Bigger and Bigger}

The third innovation that we shall consider corresponds to Major mergers and acquisitions which occurred in 1998. Halliburton first set the example by acquiring Dresser in February 1998, quickly followed by Baker Hughes in May of the same year (Table 2). It then emerged that the decision to acquire a large group was supported by the fact that the competitors considered the same strategic development. A frenzied race to bigness accordingly ensured during the year 1998 .

This acquisition strategy derived from the second innovation. In fact, to seek the maximum degree of integration, the firms were led to consider unprecedented mergers (Table 2).
TABLE 2

Mega-mergers in the oil and gas supply and service industry in 1998

\begin{tabular}{c|c|c}
\hline Buyers & Targets & Amount (G\$) \\
\hline Baker Hughes & Western Atlas & 5.5 \\
Halliburton & Dresser & 9.0 \\
Schlumberger & Camco & 3.1 \\
\hline
\end{tabular}

The acquisition by Baker Hughes of Western Atlas, the world leader in geophysics, was motivated by the quest for the integration of geophysics, drilling and boreholeassociated services. This acquisition enabled Baker Hughes to secure a position in the seismic, logging and interpretation software segment.

Halliburton merged with Dresser in 1998 in order to propose completely integrated services, but in engineering and construction. This operation also enabled the buying group to consolidate its position on the following markets: drilling services (MWD, directional drilling), drill bits and drilling fluids.

As to Schlumberger, the acquisition of the US Camco offered it a niche in which the group was not yet positioned, the drilling tools sector. Following this operation, Schlumberger covered all the trades in geophysics and drilling (and borehole-associated services).

This third innovation, which corresponded to the establishment of a new organization, is distinguished from the previous one in three ways. The first concerns the scale of the assets acquired. The capital outlay for these operations was unprecedented. The second aspect pertains to the degree of integration sought. The second innovation allowed the integration of services on a reduced segment (seismics, drilling and engineering), while the third enabled the firms to integrate beyond a service industry segment (drilling and engineering for Halliburton, seismics and drilling for Baker Hughes and Schlumberger). The third factor distinguishing these two developments is that, contrary to the second innovation, the race to bigness has sparked a wave of asset sales and refocusing.

Schlumberger was the first, selling its offshore drilling operations in 1999 to merge them with Transocean, giving birth to the world's biggest offshore drilling company (Transocean Sedco-Forex, in which Schlumberger remains a shareholder). This operation enabled Schlumberger to refocus on developing its technologies and its high-margin services. Yet this sale was offset by the acquisition of the seismic assets of Baker Hughes.

In actual fact, Baker Hughes, in 2000, sold the seismic assets it acquired in 1998. This sale led to the creation of a joint venture (Western Geco, 30\% owned by Baker Hughes and $70 \%$ by Schlumberger) which includes seismic acquisition and data processing, the multiclient libraries of Baker 
Hughes and Geco, a Schlumberger subsidiary. Note that the acquisition of Western Atlas had deeply indebted Baker Hughes, which then had to contend with a collapse of the seismic market. This sale enabled Baker Hughes to reduce its indebtedness.

Similarly, Halliburton sold Dresser Equipment Group in 2000 as part of a refocusing on its core business. The group sold the equipment operations (valves, gauges, industrial thermometers) for the energy, petrochemicals, electrical and transport industries. Halliburton thus refocused on oil and gas services.

\subsubsection{The Development of e-Business}

The latest development appears to be the growth of e-business in the oil and gas supply and service industry. Once again, we can consider this innovation as Schumpeterian because it introduces a new marketing method (Table 1). However, it is still difficult to have an overall grasp of the situation insofar as it is still in the early stages. We can simply highlight the first manifestations of this revolution within the companies examined.

It appears that Schlumberger played the leader role in setting up this new marketing method, with the creation of indigopool.com in January 2000. This Internet portal connects upstream oil and gas companies wishing to buy or sell assets and data. Thus Schlumberger is positioned on the acquisitions and divestitures market on the Internet. Added to this are many services, such as the marketing on nonexclusive seismic data.

Emulating Schlumberger, Halliburton acquired $15 \%$ of Petroleum Place in August 2000, a specialist on the Internet in the market for asset acquisitions and divestitures in the oil and gas industry.

The use of the Internet in business relations, if destined to grow, will thoroughly modify relations between sellers and buyers in the oil and gas sector, if only by shortening transaction times. Yet the use of the Internet is not limited to these two examples, as attested by the partnership between BP Amoco and Geoquest, a member of the Schlumberger group, aimed to supply technical information management services (e-solutions) in the petroleum field.

The four innovations that we analyzed above clearly reveal a pattern of imitation between the three companies examined. We even managed to identify the leaders of these developments. The second interesting point is that these mutations were chiefly achieved by relying on an external growth type strategy. Whether to redefine their core business, to broaden the range of their services or integrate on all the oil and gas service industry aspects, the firms pursued an external growth strategy that enabled them speedily to acquire the expertise held by others. Only the development of e-business appears to have been managed more by the use of internal skills.

\section{REPERCUSSIONS ON THE OVERALL OIL AND GAS SUPPLY AND SERVICE INDUSTRY}

The previous part identified a "one leader-two followers" type of company development, which applies exclusively to the three companies of the oligopoly in the sector. This part focuses on the companies forming this competitive fringe.

We have adopted the following assumption: for the competitive fringe, the company growth mode reflects a "three leaders-many followers" logic, according to which the three oligopolistic firms are now the leaders and all the smaller companies are the followers. In this part, we shall therefore test this hypothesis (3.1) and determine to what extent such a development pattern has been pursued by the competitive fringe. Once this hypothesis has been tested, we will be able to determine the form of consolidation that the sector will experience over the next few years (3.2).

\subsection{Consolidation of the Competitive Fringe}

To test our hypothesis, we shall try to see whether the innovations launched by the oligopoly have also been implemented in the competitive fringe. Our analysis of the competitive fringe is based on a sample of representative companies of the industry (Annex 2).

\subsubsection{Horizontal Growth}

Increased size has undeniably been a strategic option largely adopted by the drilling and geophysics companies since 1990. If we look at our sample, we find that among the thirty companies making it up (apart from the three oil and gas services Majors), $83 \%$ have increased their production capacity. And this applies to drilling and geophysics companies alike.

This growth chiefly occurred by external growth, as exemplified by the Nabors Industries drilling firm which made fifteen external growth operations since 1990 (Table 3).

This strategy enables the companies using it to boost their production (or services) capacity rapidly. In our example, the number of drilling rigs in activity rose from 111 in 1990 to 542 in 1999. For the same company, the total value of its assets grew from 209 million current dollars (M\$) in 1990 to M\$2398 in 1999, and its income rose from M\$139 in 1990 to M\$642 in 1999. Clearly this sharp increase in size also reinforces the financial foundation of the company, but without incurring too many risks insofar as it does not involve any new activity.

Examples of horizontal growth are numerous in the oil and gas service industry. It is interesting to note that this concentration of the sector is an answer to the development of the three Majors which, from the late 1980s, had begun to gain strength in the professions they intended to preserve. This trend hence shifted a few years later to the overall sector. Thus we are clearly in a pattern of "three leaders-many followers" as we presumed earlier in this part. 
TABLE 3

Nabors Industries acquisitions since 1990

\begin{tabular}{c|l}
\hline Year of acquisition & \multicolumn{1}{|c}{ Companies acquired } \\
\hline 1990 & Loffland Brothers Company \\
1990 & Henley Drilling Company \\
1993 & Grace Drilling Company \\
1994 & Sundowner Offshore Services \\
1995 & Delta Drilling Company \\
1996 & Canrig \\
1996 & Epoch Well Logging \\
1996 & Exeter Drilling Company \\
1997 & Cleveland Drilling Company \\
1997 & Chesley Pruet Drilling Company \\
1997 & Subsidiary of Samson Investment \\
1997 & Company \\
1998 & Adcor-Nicklos Drilling Company \\
1999 & New Prospect Drilling Company \\
1999 & Bayard Drilling Technologies \\
& Pool Energy Services \\
\hline
\end{tabular}

\subsubsection{Broadening of Services}

The second flagrant trend in the companies making up the competitive fringe is the broadening of the range of services. $50 \%$ of the companies in our sampling have pursued such a strategy. This development emerged clearly in the mid-1990s and still continues today. Unlike the companies of the oligopoly, this integration of services rarely extends beyond the initial segment to which the firm belonged: for a seismic firm, it first tries to propose comprehensive seismic services (and similarly for drilling companies).

The Norwegian firm Petroleum GeoServices-PGS-and Compagnie générale de géophysique-CGG-offer ideal examples. PGS broadened the range of its services in 1993 with the acquisition of Tensor (large acquisition and processing capabilities) and the acquisitions of ERC, Mapware and Woodlands, which enabled the PGS group to develop seismic software operations. Between 1994 and 1998, PGS extended its services to seismic acquisition in shallow waters following the acquisition of the assets of Eastern Geophysical and Northern Geophysical and of the firm Acadian. Today, like $C G G, P G S$ is active in every aspect of seismics (acquisition, processing, interpretation, data management, software etc.). This development is also significant in the drilling industry, where the players seek to offer all the links in the chain: drilling, logging, mud logging, deviation, MWD, drilling fluids, cementing, stimulation and drilling tools.

This horizontal growth and the broadening of the range of services occurred simultaneously with a large number of divestitures (business refocusing) as for the oligopoly companies. In our sample in fact, we identify eighteen divestitures after which the companies abandoned an activity.
Thus the adoption of service broadening and refocusing strategies occurred on the impetus of the service industry Majors which, to some extent, "showed the strategic route" to follow. Once again, we can find therein a "three leadersmany followers" development pattern.

In the previous part, we saw that the oligopoly firms appeared to show an interest in the development of e-business. Examples in the competitive fringe are still hard to find. The only significant example is the creation of an electronic portal (OFS Portal) in partnership with eleven service industry companies ${ }^{6}$. The aim of this joint venture is to supply a standardized electronic catalog to the customers as well as an information service on products and services offered by the participants. Thus, concerning businessto-business in the oil and gas service industry sector, it is undeniable that the three oligopoly companies launched this innovation. Owing to its very recent development, this innovation has not yet been disseminated (imitated) in the competitive fringe.

To conclude this part, the hypothesis according to which the service industry companies of the competitive fringe follow the strategic mutations of the oligopolistic firms appears to be substantiated. Yet the imitation is not clearly and distinctly perceptible in terms of time. Imitation takes place with a certain lag, which varies according to the innovations. We found in fact that the quest for bigness emerged belatedly in the competitive fringe, whereas the broadening of the range of services took place virtually simultaneously with the oligopoly companies. This lag means that the reorganization of the oil and gas supply and service sector is not yet complete.

\subsection{Consolidation Prospects of the Oil and Gas Supply and Service Sector}

The quest for a critical size will very probably continue in the oil and gas service industry. In fact, some firms will try to settle between the competitive fringe and the oligopolistic group. These firms, which would thus wish to enter into direct competition (in terms of size) with the oligopoly firms, will initially attempt to secure positions on markets where the Majors are relatively absent.

Drilling is a market left vacant by the oligopoly, and this is why we will very probably witness a new wave of consolidations in the drilling sector. In fact, this trend has already begun with the attempt to buy $R \& B$ Falcon by Transocean Sedco-Forex in 2000, which will place this new firm in the top rank worldwide offshore drilling, and in third place in oil and gas services. We are hence witnessing the birth of a fourth firm in the oligopoly.

(6) ABB, BJ Services, Cooper Cameron, ENSCO, FMC, Halliburton, National Oilwell, Schlumberger, Smith International, Transocean Sedco-Forex and Weatherford. The interesting point is that the three service industry Majors participate in this joint venture. 
Moreover, the acquisition of the Baker Hughes seismic operations by Schlumberger in 2000 was perceived as an offensive maneuver by the geophysics companies in the competitive fringe. To strike back, it is also very likely that these seismic firms will seek consolidation through largescale mergers. Why not imagine a merger between $C G G$, $P G S$ and/or Veritas? Yet these operations are unlikely before the seismic market recovers a growth pattern.

The second factor that the sector will see is continued broadening of the range of services offered. Once these new large groups have been formed and have reached optimal size (sufficient economies of scale for the firms to be profitable), they will seek to broaden the range of their services while remaining within their industrial segment. They will not try to occupy new activities because of the clear failure of this strategy among the service industry Majors (remember the wave of refocusing that followed the Major acquisitions of 1998). Besides, it is unlikely that they will adopt this strategy before having reached critical size. In fact, the supply of new services, even belonging to the same industrial segment as those already proposed, can incur a risk for the company (will it find the anticipated synergies, will the market welcome the new service?). Before taking this risk, the firm will prefer to have a sufficiently solid financial foundation, backed by impressive size. Furthermore, as the company grows, and offers increasingly numerous services, it will try to sell off the operations that it finds the least profitable. Alongside the formation of these large groups, other firms will prefer to specialize, occupy industrial niches.

Thus it appears clearly that the oil and gas supply and service sector has not yet completed its restructuring, and that the wave of consolidations will continue in the coming years, in the patterns that we have described. Yet it is difficult to determine when the next wave of mergers and acquisitions will materialize, insofar as the strategic decisions of this sector are taken in close consideration of the trend in crude oil prices.

\section{CONCLUSION}

These developments have enabled us to identify the Major role played by the oil and gas supply and service Majors in the implementation of innovations according to Schumpeter's terminology. It was also interesting to find that these three firms pursued a similar development mode in the last decade. Even more interesting was to see to what extent they play an influential role in the entire sector. Yet this result must be seen in relative terms. The company that makes such an innovation (that plays the leader role) acts in accordance with a set of constraints it faces, together with the overall sector. It is normal for the first company or companies to respond to a new constraint to be a large firm which has financial resources and extensive managerial skills.
The companies of the competitive fringe managed to profit from the experiences of the oligopoly. In fact, they only pursued strategies that have functioned for the three leaders, while taking care to avoid committing the same errors (excessive diversification, for example).

The development mode of the oil and gas supply and service companies, presented in an oligopoly/competitive fringe dichotomy, can apply to any economic sector displaying a similar structure of the players. Insofar as a few firms dominate an industry, they serve as a "test" in strategic terms for smaller companies. This was in fact what Porter (1982) said when he stated that the competitive battle between the groups of the industrial sector is one of the types of competition. Thus the developments discussed above offer an original justification for the concentration of a sector. The results that we obtain enable us in fact to justify the wave of consolidation of the companies by the fact that they emulate the strategies implemented by competing firms. It is not a new fact, but it is in the systematization of the "leaderfollowers" pattern that the originality of the approach lies.

\section{ACKNOWLEDGEMENTS}

I would like to thank Nathalie Alba-Saunal for her support and suggestions. I am also very grateful to ENSPM Formation Industrie and Institut français du pétrole for their financial support.

\section{REFERENCES}

Bienaymé, A. (1994) L'économie des innovations technologiques, Presses universitaires de France, coll. Que sais-je ?, Paris.

Le Dortz, L. (1999) Énigmes schumpétériennes et dynamiques évolutionnistes des industries : une mise en perspective, in Basle, M., Delorme, R., Lemoigne, J.L. and Paulré, B., Approches évolutionnistes de la firme et de l'industrie, L'Harmattan, coll. Dynamiques d'entreprises, Paris.

Porter, M. (1982) Choix stratégiques et concurrence, Economica, Paris.

Schumpeter, J.A. (1935) Théorie de l'évolution économique, Dalloz, Paris.

Schumpeter, J.A. (1942) cf. Introduction.

Schumpeter, J.A. (1947) Capitalisme, socialisme et démocratie, Bibliothèque historique Payot, Paris.

Teece, D.J. (1978) Vertical Integration in the US Oil Industry, in Mitchell, E.J., Vertical Integration in the Oil Industry, American Enterprise Institute for Public Policy Research, 105-189.

Williamson, O.E. (1975) Market and Hierarchies: Analysis and Antitrust Implications, The Free Press, New York.

Williamson, O.E. (1985) The Economic Institutions of Capitalism, The Free Press, New York.

Final manuscript received in November 2001 
ANNEX 1

THE THREE LEADERS IN THE OIL AND GAS SUPPLY AND SERVICE INDUSTRY

\section{Size of the Three Majors}

\begin{tabular}{l|c|c|c|c|c}
\hline $\mathbf{3 1 / 1 2 / 1 9 9 9}$ & $\begin{array}{c}\text { Stock market } \\
\text { capitalization } \\
\text { on 8/4/2000 (M\$) }\end{array}$ & Income (M\$) & $\begin{array}{c}\text { Asset value } \\
\text { (M\$) }\end{array}$ & $\begin{array}{c}\text { Workforce } \\
\text { (thousands) }\end{array}$ & International presence \\
\hline $\begin{array}{l}\text { Halliburton } \\
\text { (United States) }\end{array}$ & 21427 & 14898 & 10728 & 103 & $\begin{array}{l}\text { Active in } 122 \text { countries, including the } \\
\text { United States (32\% of income) and the } \\
\text { United Kingdom (12\%) }\end{array}$ \\
\hline $\begin{array}{l}\text { Schlumberger } \\
\text { (United States, France) }\end{array}$ & 44289 & 8395 & 15081 & 55 & $\begin{array}{l}\text { Internationally active. For oil and gas } \\
\text { services, North America accounts for } 25 \% \\
\text { of income and the Europe/CIS/West Africa } \\
\text { zone for 23\% }\end{array}$ \\
\hline $\begin{array}{l}\text { Baker Hughes } \\
\text { (United States) }\end{array}$ & 12073 & 4547 & 7040 & 27 & $\begin{array}{l}\text { Active in 70 countries, including the United } \\
\text { States (37\% of income), the United } \\
\text { Kingdom (9\%) and Norway (6\%) }\end{array}$ \\
\hline
\end{tabular}

Source: 1999 annual reports

\section{Integration of the Majors}

\begin{tabular}{|c|c|c|c|c|c|c|c|c|c|c|c|c|c|c|c|c|}
\hline & \multicolumn{3}{|c|}{ Geophysics } & \multicolumn{7}{|c|}{$\begin{array}{l}\text { Drilling - Equipment and } \\
\text { associated services }\end{array}$} & \multicolumn{5}{|c|}{$\begin{array}{l}\text { Engineering and } \\
\text { offshore operations }\end{array}$} & \\
\hline & 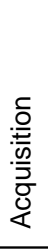 & 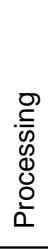 & 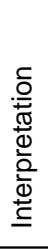 & 趌 & 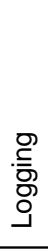 & 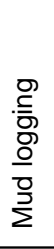 & 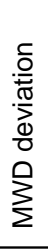 & 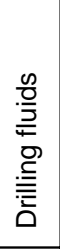 & 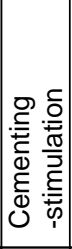 & 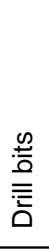 & 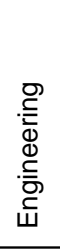 & 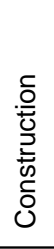 & 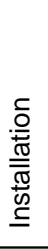 & 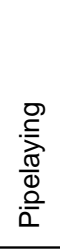 & 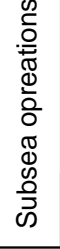 & $\begin{array}{l}99 \text { income } \\
(\mathrm{G} \$)\end{array}$ \\
\hline Halliburton & & & & & & & & & & & & & & & & 14.9 \\
\hline Schlumberger & & & & & & & & & & & & & & & & $5.9^{*}$ \\
\hline Baker Hughes & & & & & & & & & & & & & & & & 4.5 \\
\hline
\end{tabular}

* "Oil and gas services" income 
ANNEX 2

COMPOSITION OF THE SAMPLING

\begin{tabular}{|c|c|c|}
\hline Integrated Majors & Geophysics companies & Drilling companies \\
\hline $\begin{array}{l}\text { Baker Hughes } \\
\text { Halliburton } \\
\text { Schlumberger }\end{array}$ & $\begin{array}{l}\text { Arcis Corp } \\
\text { CGG } \\
\text { Dawson Geophysical } \\
\text { Grant Geophysical } \\
\text { Input Output } \\
\text { Oyo Geospace } \\
\text { Paradigm Geophysical } \\
\text { PGS } \\
\text { Seitel } \\
\text { Veritas DGC }\end{array}$ & $\begin{array}{l}\text { Diamond Offshore } \\
\text { ENSCO International } \\
\text { Ensign Resource Services } \\
\text { Global Marine } \\
\text { Grey Wolf } \\
\text { Helmerich \& Payne } \\
\text { Marine Drilling } \\
\text { Nabor Industries } \\
\text { Noble Drilling } \\
\text { Parker Drilling } \\
\text { Patterson Energy } \\
\text { Precision Drilling } \\
\text { Pride International } \\
\text { R\&B Falcon } \\
\text { Rowan Companies } \\
\text { Santa Fe International } \\
\text { Smedvig } \\
\text { Transocean Sedco-Forex } \\
\text { Unit Corporation } \\
\text { UTI Energy Corp }\end{array}$ \\
\hline
\end{tabular}

